Red. prof. dr.

Sonja Kump

Filozofska fakulteta Univerze $v$ Ljubljani

\title{
IZOBRAŽEVANJE ODRASLIH V EVROPSKEM LETU DRŽAVLJANOV
}

\section{POVZETEK}

Izhodišče prispevka je letošnja tema evropskega leta, ki v središče postavlja aktivno državljanstvo, skupaj z razlogi Evropske komisije za odločitev o letu državljanov. V nadaljevanju so predstavljene sodobne razprave o družbenoemancipacijskih namenih politik izobraževanja odraslih v preteklosti in sedanje opazne spremembe $v$ političnih dokumentih. Posebna pozornost je namenjena vlogi izobraževanja za aktivno državljanstvo v radikalni tradiciji izobraževanja odraslih in v najnovejših družbenih gibanjih, kjer je vsakdanja izkušnja pomemben vir učenja, ki pa jo je treba kritično reflektirati in okrepiti v dialoških razpravah, študijah in delovanju.

Ključne besede: aktivno državljanstvo, politika izobraževanja odraslih, radikalno izobraževanje, sodobna družbena gibanja, izobraževanje odraslih

\section{ADULT EDUCATION IN THE EUROPEAN YEAR OF CITIZENS - ABSTRACT}

The paper refers to this year's European year of active citizenship and the reasons for the European Commission's decisions in relation with this topic. In the continuation, the paper presents current debates on historical characteristics of the social emancipation aims in adult education policies and new shifts, discernable in political documents. Special attention is devoted to the role of education for active citizenship in the radical tradition and in the newest social movements, in which everyday experience constitutes an important source of learning. This needs to be critically reflected and reinforced through dialogical debates, studies and activities.

Keywords: active citizenship, adult education policy, radical adult education, the newest social movements, adult education

UDK: 374.7

\section{UVOD}

Razglasitev leta 2013 za evropsko leto državljanov, katerega slogan se glasi »Za Evropo gre. Za vas gre.«, je primerna iztočnica za razmislek o vlogi izobraževanja odraslih za aktivno državljanstvo. Različni politični dokumenti o izobraževanju odraslih na nadnacionalni in nacionalni ravni uvrščajo aktivno državljanstvo med cilje svojih politik. Toda pojmovanje aktivnega državljanstva se $\mathrm{v}$ teh dokumentih spreminja skozi čas in je odvisno od umeščenosti v različne družbene, gospodarske in politične kontekste.

Eden od razlogov za to, da je Evropska komisija leto 2013 razglasila za leto drža- vljanov, je 20-letnica državljanstva EU, ki je bilo uvedeno leta 1993 z začetkom veljavnosti Maastchtritske pogodbe. Naslednji razlog so volitve v Evropski parlament leta 2014. Komisija se zaveda, da se volilna udeležba zmanjšuje in da imajo evropski državljani občutek izključenosti iz procesov odločanja (t. i. demokratski deficit). Vse več je tudi tistih, ki zavračajo Pogodbo o ustavi za Evropo in Lizbonsko pogodbo. Tako med Evropejci narašča zavedanje, da se cilji Lizbonske strategije, ki je načrtovala, da bo Evropa do leta 2010 najbolj konkurenčno, dinamično in na znanju temelječe gospodarstvo na svetu, niso uresničili, saj Evropa preživlja obdobje dolgotrajne recesije. Zaradi naštetih razlogov je Evropska 
komisija ustanovila poseben program za podporo aktivnemu evropskemu državljanstvu - Evropa za državljane. Za obdobje 2007-2013 je Komisija programu, ki vključuje več tematskih sklopov, namenila 215 milijonov evrov (Europe for Citizens Programme, 2013). Po pregledu odobrenih projektov in podpor lahko ugotovimo, da je bila Slovenija $v$ zadnjih šestih letih največkrat vključena v t. i. akcije »Srečanje državljanov na podlagi pobratenja mest « in »Mreže pobratenih mest $\ll$. V preostalih šestih tematskih sklopih je bila Slovenija deležna le nekaj drobtinic. Razloga za tako skromno podporo našim državljanom iz spletnega portala programa ne moremo razbrati in lahko le ugibamo, ali je vzrok v slabi obveščenosti o programu ali pa v neuspešnih prijavah.

Za Evropsko komisijo državljanstvo EU pomeni dopolnitev nacionalnega državljanstva in dodatne pravice, ki vključujejo svobodo gibanja znotraj EU, pravico voliti in biti voljen na lokalnih in evropskih volitvah v državi članici EU, pravico do konzularne zaščite v tuji državi pod enakimi pogoji kot njeni državljani ter pravico nasloviti peticijo na Evropski parlament, pritožiti se pri varuhu človekovih pravic in od leta 2012 naprej sodelovati pri evropski državljanski pobudi (Evropska komisija - Slovenija 2013). Odmevni uveljavitvi teh zadnjih pravic sta denimo peticija, ki je preprečila ratifikacijo mednarodnega trgovinskega sporazuma Acta (peticijo je podpisalo 2,5 milijona Evropejcev), in še vedno aktualna državljanska pobuda proti »privatizaciji vode«, ki jo je podpisalo že več kot milijon Evropejcev.

Opredelitev aktivnega državljanstva, kot ga razume Komisija, je le ena v vrsti številnih definicij. Samo Davies (1999) jih je naštel prek 300. Kljub raznolikosti so skupni elementi različnih definicij politična participacija, participacija v družbenem življenju, ki temelji na toleranci in nenasilju, ter priznavanje prava in človekovih pravic. Definicije aktivnega državljanstva se razlikujejo tudi po državah; v nekaterih aktivno državljanstvo povezujejo s prostovoljstvom, aktivnim sodelovanjem pri odločanju o stvareh, ki zadevajo skupnost, z razvojem socialnega kapitala in mreženjem.

\section{POLITIKE IZOBRAŽEVANJA ODRASLIH, DRUŽBENA EMANCIPACIJA IN AKTIVNO DRŽAVLJANSTVO}

Države lahko s svojimi politikami izobraževanja odraslih spodbujajo ali zavirajo posamezna področja znotraj tega izobraževanja. Tako lahko s podpiranjem jasno opredeljenega izobraževanja za aktivno državljanstvo krepijo demokratično participacijo državljanov ali pa zgolj zameglijo njen pomen. Pri razmisleku o vlogi nacionalnih politik pri izobraževanju za aktivno državljanstvo je umestno vprašanje, ki sta ga v svojem prispevku postavila portugalska avtorja (Fragoso in Guimarães, 2010): Ali je v javnih politikah še kaj prostora za družbeno emancipacijo? Odgovor sta iskala skozi zgodovinski razvoj javnih politik izobraževanja odraslih v zahodnih demokracijah, ki so se začele oblikovati v času po drugi svetovni vojni. V tem obdobju se je utrjevala država blaginje, ki je nastajala $\mathrm{v}$ razmerah gospodarske rasti in polne zaposlenosti. Griffin (1999) meni, da je bilo vpeljevanje javnih politik izobraževanja odraslih posledica razglasitve družbene pogodbe med kapitalom in državnim urejanjem dela, ki je povezovala kapitalizem in demokracijo. Prednostne naloge tedanjih politik so bile osredinjene na demokratizacijo družbe, večanje družbene blaginje in gospodarsko rast (Olssen, 2006). To je bil tudi čas, ko so države izdatno finančno podpirale 
in hkrati nadzirale izobraževalno ponudbo. S priznavanjem neformalnega splošnega izobraževanja za osebnostno rast in aktivno državljanstvo so pomembno vlogo dobile organizacije civilne družbe.

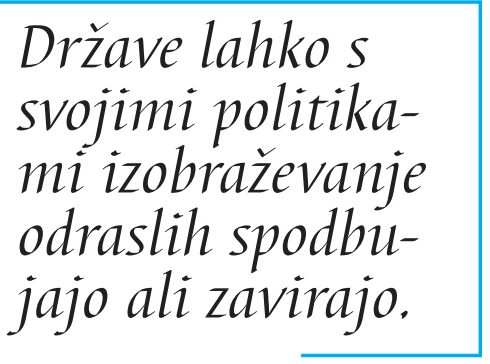

V 70. letih, ko so se kljub povečanim javnim izdatkom za izobraževanje večale neenakosti v izobraževalnih dosežkih, posledično pa so se večale tudi socialne in ekonomske neenakosti, je velik vpliv na nacionalne politike izobraževanja imelo Unescovo poročilo (Faure in drugi, 1972). V duhu humanistične tradicije so avtorji poročila trdili, da bo vseživljenjsko učenje pripomoglo h graditvi boljše družbe in doseganju višje kakovosti življenja. Njihovo sporočilo je bilo jasno: družbena emancipacija za vse. Poudarek je bil na splošni izobraženosti, kulturi in zagotavljanju enakih možnosti ter vzpostavitvi sistema vseživljenjskega učenja, ki naj bi v celotni družbi zmanjšal neenakosti na področju izobraževanja. Za izobraževanje odraslih, ki so ga pojmovali kot javno dobro in temeljno človekovo pravico, je bil značilen družbeni namen (Martin, 2006), saj si je prizadevalo za družbeno in politično spremembo, katere rezultat naj bi bila večja družbena pravičnost, enakost in kultura dialoga. Država, civilna družba in družbena gibanja so razvijali programe za izboljšanje demokracije, ki so vključevali kritično refleksijo o družbenem delovanju in političnem vključevanju državljanov. Skratka, cilji politik izobraževanja odraslih, v katerih sta prevladovala pojma »vseživljenjsko izobraževanje« in »znanje«, so bili do 80. let tesno povezani s socialno vključenostjo, pripravo delavcev za gospodarski razvoj ter $\mathrm{z}$ emancipacijo in demokratičnim državljanstvom.
Začetek sprememb v politikah izobraževanja odraslih je povezan $\mathrm{z}$ globalizacijo in uveljavljanjem neoliberalne ideologije, ki zagovarja »novo ekonomijo«, zasnovano na načelih svobodnega trga. Premiki v politikah (zdaj tesno povezanih s pojmoma »vseživljenjsko učenje « in »kompetence«) se kažejo v oženju koncepta in instrumentalizaciji ciljev izobraževanja odraslih, prilagojenih ekonomskim imperativom; izobraževanje odraslih je vse bolj instrument za povečevanje konkurenčnosti gospodarstva $\mathrm{v}$ globaliziranem svetu.

Nove smernice $\mathrm{v}$ oblikovanju nacionalnih politik izobraževanja odraslih so povezane z objavo poročila OECD o izobraževanju in gospodarstvu v spreminjajoči se družbi (OECD, 1989). Ta izobraževalna agenda ni bila narejena le s pozicije človeškega kapitala, ampak je slonela tudi na neoliberalnem okviru, ki je nadomestil keynesijansko državo blaginje. Ekonomski imperativ, ki je poganjal izobraževalne politike, se je izražal v številnih krčenjih javne porabe, splošnem sumničenju javnih ustanov (povečalo se je število evalvacij, povezanih z odgovornostjo) in v prepričanju o veliki učinkovitosti svobodnega trga. Razprave o vseživljenjskem učenju so se vrtele znotraj političnoekonomskega imperativa, ki je poudarjal pomen visoko usposobljenega človeškega kapitala, znanosti in novih tehnologij. Vse to pa naj bi podpiralo prestrukturiranje gospodarstva, povečano produktivnost in mednarodno tekmovalnost.

Pomemben vpliv na oblikovanje politik izobraževanja odraslih je imel tudi Memorandum o vseživljenjskem učenju (European Commission 2000), v katerem je Evropska komisija izhajala iz teze, da so sodobne družbene in gospodarske spremembe medsebojno povezane. Tako Memorandum poudarja dva enako pomembna cilja vseživljenjskega učenja: »Pospeševanje aktivnega 
državljanstva in pospeševanje zaposljivosti sta enako pomembna in medsebojno povezana cilja. Zaposljivost - sposobnost zagotoviti si in obdržati zaposlitev - ni samo temeljna dimenzija aktivnega državljanstva, temveč je odločilen pogoj tudi za dosego polne zaposlenosti in za izboljšanje evropske tekmovalnosti ter prosperitete $\mathrm{v}$, novi ekonomiji'. Oboje, zaposljivost in aktivno državljanstvo, je odvisno od primernega in sodobnega znanja ter spretnosti, kar omogoča posamezni$\mathrm{ku}$, da sodeluje in tudi prispeva $\mathrm{k}$ skupnemu ekonomskemu in družbenemu življenju.« (European Commission, 2000: 4) Kot ugotavlja Rubenson (2004), ima v Memorandumu osrednjo vlogo trg, opazna pa je tudi retorika o deljeni odgovornosti in medsebojnem delovanju trga, posameznikov in države. Vendar natančno prebiranje dokumentov EU od leta 2000 dalje razkrije, da je poudarek predvsem na posameznikih, ki so na koncu sami odgovorni, da se nenehno učijo. Tako se vseživljenjsko učenje kaže kot izrazito individualen projekt; posameznik je odgovoren, da izbere ustrezno izobraževalno ponudbo, da ustvarja in ohranja svoj človeški kapital.

Tudi aktualni strateški dokument Sveta EU »Izobraževanje in usposabljanje 2020 « (ET 2020) izhaja iz memorandumskega načela, da se zaposljivost in aktivno državljanstvo prekrivata in medsebojno podpirata. V tretjem strateškem cilju Spodbujanje pravičnosti, socialne kohezije in aktivnega državljanstva pravi, »da bi morala politika izobraževanja in usposabljanja vsem državljanom ne glede na njihove osebne, socialne ali gospodarske razmere omogočiti vseživljenjsko pridobivanje, posodabljanje in razvoj znanj in spretnosti, pomembnih za specifična delovna mesta, pa tudi ključnih kompetenc, potrebnih za njihovo zaposljivost ter pospeševanje nadaljnjega učenja, aktivnega državljanstva in medkulturnega dialoga .
V zadnjih 20 letih, v kontekstu globalizacije, ko so nacionalne politike izobraževanja odraslih zasnovane na nadnacionalnih direktivah, je poudarek na zasebnem, individualiziranem učenju in na usposabljanju delavcev zaradi njihove večje produktivnosti. Spodbuja se javna in zasebna izobraževalna ponudba, ki deluje po menedžerskih pravilih in postopkih. Na hegemonski vpliv, ki ga imajo nadnacionalne organizacije pri oblikovanju nacionalnih politik izobraževanja odraslih, opozarjajo kritični avtorji (Barros, 2012; Fragoso in Guimarães, 2010; Rubenson, 2009; Olssen, 2006), ki ugotavljajo, da zlasti OECD in EU vsiljujeta direktive glede vseživljenjskega učenja, ki so tesno prepletene s teorijo človeškega kapitala, poklicnim usposabljanjem in prevlado ideologije kompetenc - seveda pa takšne usmeritve ignorirajo humanistično in družboslovno izobraževanje, saj je v njihovem kontekstu odveč, če ne celo moteče. Oblikovanje nacionalne politike izobraževanja odraslih tako ni več izključno v pristojnosti države, kajti opazno naraščata moč in vpliv nadnacionalnih organizacij, ki s svojo »mehko prisilo« (finančne spodbude ob hkratnem širjenju evalvacij rezultatov nacionalnih politik izobraževanja, kot so npr. PISA, IALS, PIAAC) določajo prioritetna področja izobraževanja odraslih. Zaradi tega države pri oblikovanju svojih politik vse manj upoštevajo svoje posebne zgodovinske in kulturne okoliščine ter postajajo glede na politike vse bolj homogene.

Politike izobraževanja odraslih tako na nacionalni kot na nadnacionalni ravni omenjajo izobraževanje za aktivno državljanstvo, toda mnogi avtorji opozarjajo, da gre le za dimno zaveso, saj je kot glavna poteza aktivnega državljanstva predstavljena zaposljivost (Jarvis, 2007). R. Barros ugotavlja, da se sedanje politike 
izobraževanja odraslih kljub retoriki v bistvu ne zavzemajo za socialno pravičnost, ampak zagovarjajo predvsem socialni mir, ki se lahko hitro sprevrže v nove oblike zatiranja (Barros, 2012: 131). V tem smislu postaja izobraževanje odraslih sredstvo za preprečevanje socialnega konflikta. Kljub političnim deklaracijam o spodbujanju socialne kohezije in boja proti socialni izključenosti smo priče sistematičnemu naraščanju brezposelnosti, širjenju revščine, vse večji negotovosti zaposlitve in zniževanju realnih plač, naraščanju družbene neenakosti ob hkratnem naraščanju korupcije in bogatenju elit. V takšnih okoliš̌činah je množična ponudba izobraževanja odraslih predstavljena kot nova priložnost za zaposlitev. Barros to interpretira kot način brzdanja nasilja, kot neke vrste varnostni ventil ali blažilni dejavnik v upravljanju brezposelnosti.

Tudi kadar politični dokumenti vseživljenjsko učenje povezujejo s socialno kohezivnostjo in aktivnim državljanstvom, ostajajo ti pojmi nejasni, ker se znanje ne povezuje s politično in ekonomsko močjo v družbi. Murphy v tej zvezi opozarja, da gre v politikah vseživljenjskega učenja v bistvu za fleksibilno državljanstvo in delovno silo, ki zadovoljuje selektivne interese kapitalistične politične ekonomije pod krinko krepitve moči in progresivnega izobraževanja za vse (Murphy, 2000: 176).

Martin (2003) je prepričan, da gre v politikah izobraževanja odraslih (ki so zdaj del politik vseživljenjskega učenja) za popolnoma nov namen in organizacijo izobraževanja odraslih, ki je oblikovano kot odprt, decentraliziran in tržno naravnan sistem, prilagojen delu in potrošništvu. Po mnenju Crowtherja (2004: 127) pomanjkljivost prevladujočega diskurza o vseživljenjskem učenju ni v prvi vrsti njegova zoženost na poklicno usposabljanje oz. profesionalno učenje (ki je samo del vseživljenjskega učenja), ampak skrita agenda ustvarjanja prilagodljivih, nepovezanih, discipliniranih in ustrahovanih delavcev in državljanov. Avtor opozarja na zgrešenost razmišljanja o tem, da je vseživljenjsko učenje le bolj popularna oblika vseživljenjskega izobraževanja, kajti zgodilo se je nekaj novega in usodnejšega. Prevladujoči diskurz vseživljenjskega učenja namreč postaja način družbenega nadzora, ki deluje kot nova tehnologija discipliniranja; ljudi dela pohlevnejše in sprijaznjene s »krasnim novim svetom « fleksibilnega kapitalizma. Po ocenah več avtorjev (npr. Crowther, 2004; Olssen, 2006; Martin, 2003; in drugi) vseživljenjsko učenje zožuje javno sfero, spodkopava izobraževalno dejavnost, uvaja nove mehanizme samonadzorovanja in samodiscipliniranja ter krepi prepričanje, da je za neuspeh odgovoren posameznik. V tej perspektivi je vseživljenjsko učenje »deficitarni diskurz«, ki odgovornost za ekonomski in politični neuspeh premešča s sistemske ravni na raven posameznika. Vseživljenjsko učenje je postalo del nove, manj očitne oblike nadzorovanja in upravljanja ljudi. Po Bourdieuju je »fleksploatacija « nov način dominacije, ki temelji na ustvarjanju splošnega in permanentnega stanja negotovosti s ciljem, da so delavci prisiljeni $\mathrm{v}$ pohlevnost in sprejemanje prekarnega dela (Bourdieu, 1998: 85). Kot meni Coffield, je s perspektive delodajalca idealen delavec tisti, ki hitro internalizira potrebo po zaposlenosti, ki je pripravljen plačati svoje nenehno učenje in ki je prožno pripravljen opravljati vsako delo, tudi če je le začasno in slabo plačano (Coffield, 2002: 185). V tem smislu je vseživljenjsko učenje del hegemonskega projekta internalizacije pohlevnosti in ustrežljivosti. 
R. Barros (2012) trdi, da v današnjem svetu, kjer se ustvarja nenehna klima negotovosti in tveganja, ljudje postajajo vse bolj osamljeni, izolirani in družbeno nezaščiteni. V teh razmerah splošnega občutka razočaranja in odtujenosti pa je odgovornost ljudi, da se vseživljenjsko učijo ter postanejo kompetentni in konkurenčni delavci. $\mathrm{V}$ skladu $\mathrm{z}$ neoliberalno utopijo je kompetenten delavec prilagodljiv, njegovo osebno delovanje pa je zreducirano na poklicno delo in vlogo dobrega potrošnika. Seveda pa takšen državljan, ki je kompetenten le za delo in potrošnjo, ne postavlja odvečnih vprašanj in ne problematizira nepravične družbene realnosti. V tej zvezi je pomenljiv letošnji nagovor Viviane Reding, podpredsednice Evropske komisije, pristojne za pravosodje, temeljne pravice in državljanstvo: »Državljani od Evrope pričakujejo konkretne rezultate in natanko to jim zagotavljamo: cenejše gostovanje v mobilnih omrežjih, večje pravice za žrtve kaznivih dejanj in preprostejše spletno nakupovanje.« (Evropska komisija - Slovenija 2013) Iz njenih besed lahko razberemo, da je pomemben poudarek na evropskih državljanih kot dobrih potrošnikih. Nič pa ne izvemo o brezposelnih evropskih državljanih (decembra 2012 jih je bilo že okoli 26 milijonov) in njihovih pravicah do dostojnega življenja. Brezposelni so v luči bruseljske administracije slabi potrošniki, saj nimajo sredstev za spletno nakupovanje in cenejše gostovanje $\mathrm{v}$ mobilnih omrežjih. Tako ostajajo individualizirani, pogosto celo patologizirani in osramočeni zaradi svojega položaja ekonomsko neaktivnih državljanov.

Kritiki opozarjajo, da v sodobnih politikah vseživljenjskega učenja ni najmanjše sledi tradicionalnih idej izobraževanja odraslih, ki so bile povezane s socialnimi nameni, političnim angažmajem in vizijo boljšega sveta (Borg in Mayo, 2006: 23). Glav- ni namen novih politik je povečati ozko opredeljene spretnosti in prožnost delovne sile. Gre torej za poklicno izobraževanje in usposabljanje, katerega cilj je ekonomska konkurenčnost. Skratka, sedanje izobraževanje odraslih je podrejeno ekonomskim ciljem in dobiva vse bolj instrumentalen značaj. V ozadju je čisti politični interes za usposabljanje učinkovite in produktivne delovne sile. Zelo malo je še tistega, kar naj bi predstavljalo »prostovoljno, samomotivirano prizadevanje za znanje $\ll$.

Vprašanje je torej, koliko je $\mathrm{v}$ sodobno izobraževanje odraslih vključeno ozaveščanje ljudi tudi z drugega, neekonomskega vidika, kot je npr. spodbujanje kritičnega mišljenja, aktivnega državljanstva in preseganje ozkega razumevanja znanja kot ekonomske kategorije v funkciji potreb dela. Fragoso in Guimarães (2010: 29) ugotavljata, da so nekdanje značilnosti izobraževanja odraslih, kot so družbena emancipacija, humanistični temelji, kritično delovanje, aktivno državljanstvo in druga dragocena načela, pozabljena. Zdaj v izobraževanju odraslih prevladujejo diskurzi gospodarske rasti, kompetenc, kvalifikacij in človeških virov ter ozko razumevanje usposabljanja, ki naj zagotavlja bolj usposobljene delavce. Današnje politike izobraževanja odraslih imajo korozivne učinke na tisto ponudbo izobraževanja, ki vključujejo socialne, emancipacijske in politične dimenzije izobraževanja. Nekdanja vez med izobraževanjem odraslih in družbeno emancipacijo je v tej politiki pretrgana. Posledica novih usmeritev v politikah je zoženje polja izobraževanja odraslih; po eni strani se pozablja na vrednote (izvore, dediščino, tradicijo), ki so pripomogle k razvoju izobraževanja odraslih, kot so družbena emancipacija in kritično delovanje ter mišljenje; po drugi strani pa izobraževanje odraslih postaja instrument usposabljanja delavcev za potrebe 
novega trga dela (s prevlado prekarnih, prožnih in slabo plačanih zaposlitev) (Fragoso in Guimarães, 2010: 22). Glavni cilj izobraževanja odraslih je preživetje na trgu dela, ki postaja vse bolj tekmovalen.

\section{AKTIVNO DRŽAVLJANSTVO V NACIONALNEM PROGRAMU IZOBRAŽEVANJA ODRASLIH}

Temeljni strateški dokument o izobraževanju odraslih v Sloveniji je Resolucija o nacionalnem programu izobraževanja odraslih (ReNPIO), ki je bila prvič sprejeta za obdobje 2005-2010. Na podlagi ReNPIO vlada vsako leto sprejme program izobraževanja odraslih, s katerim se določajo izobraževalni programi in dejavnosti. Z letnim programom izobraževanja odraslih se določajo tudi prioritete na treh prednostnih področjih, ki jih opredeljuje ReNPIO (splošno izobraževanje in učenje odraslih, izobraževanje za dvigovanje izobrazbene ravni ter izobraževanje in usposabljanje za potrebe trga dela). Koliko se v posameznem letu finančno podprejo posamezni prioritetni izobraževalni programi, je odvisno od razmerja moči in vplivov na pristojnih ministrstvih. Glavna financerja izobraževanja odraslih sta ministrstvo za izobraževanje, znanost, kulturo in šport ter ministrstvo za delo, družino in socialne zadeve.

Iz analize ReNPIO 2005-2008 (Beltram in drugi, 2010: 7) je razvidno, da so se cilji v najmanjši meri uresničili v okviru splošnega izobraževanja in učenja odraslih (kamor je uvrščeno tudi izobraževanje za aktivno državljanstvo), poudarek pa je bil na izobraževanju in usposabljanju za potrebe trga dela. Kljub politični retoriki je opazno preusmerjanje financiranja od splošnega $\mathrm{k}$ poklicnemu izobraževanju oz. izobraževanju za zaposljivost, kar je sicer splošna težnja v EU, ki temelji na tihih priporočilih evropske politike izobraževanja odraslih.

Za namen analize so na Andragoškem centru Slovenije izvedli poskusno različico aplikacije za spremljanje uresničevanja ReNPIO; vanjo so vnesli podatke iz poročil izvajalcev o izvedbah programov, izbranih na podlagi razpisov, ki ju je za leti 2007 in 2008 objavilo ministrstvo za šolstvo in šport. Pri analizi podatkov so se omejili na programe iz splošnega izobraževanja. V razpisnih pogojih ministrstva za šolstvo in šport za leti 2007 in 2008 so bili splošni programi razdeljeni v naslednje vsebinske sklope: aktivno državljanstvo, izobraževanje starejših odraslih, izobraževanje odraslih s posebnimi potrebami ter izobraževanje pripadnikov manjšin in Romov. Iz analize lahko razberemo, da je bilo leta 2007 izvedenih 44 programov aktivnega državljanstva, v letu 2008 pa 55 (Beltram in drugi, 2010: 21). Iz podatkov, ki jih za namene spremljanja uresničevanja ReNPIO zbira Andragoški center Slovenije, smo ugotovili, da je bilo največ programov za aktivno državljanstvo sofinanciranih leta 2009, in sicer 128 , njihovo število se je do leta 2011 skrčilo na 83 .

V letu 2011 je ministrstvo za šolstvo in šport objavilo javni razpis za sofinanciranje programov splošnega neformalnega izobraževanja odraslih od leta 2012 do 2014 (sredstva Evropskega socialnega sklada), ki naj bi zviševali splošno izobraženost in razvijali ključne kompetence (mednje so uvrščene tudi socialne in državljanske kompetence) odraslega prebivalstva za dejavno vključevanje $\mathrm{v}$ življenje in delo. Iz rezultatov tega razpisa lahko razberemo, da je bilo za tri razpisana leta odobrenih 410 programov neformalnega splošnega izobraževanja odraslih, ki niso razvrščeni po posameznih področjih (Rezultat razpisa, 2011). Iz naslovov programov lahko razberemo, da je bilo izbranih največ jezikovnih in računalniških 
programov, programov za večanje zaposljivosti in razvoj podjetništva. Programov za aktivno državljanstvo je bilo odobrenih le peščica. Med izvajalci prevladujejo ljudske univerze in zasebne izobraževalne organizacije. Informacije o programih za aktivno državljanstvo smo iskali tudi na spletnem portalu Andragoškega centra Slovenije »Kam po znanje«; zanimivo je, da se pri iskanju aktivnega državljanstva izpišejo štirje izobraževalni programi, po podrobnejšem pregledu pa je razvidno, da gre $\mathrm{v}$ bistvu le za en program aktivnega državljanstva, ki je namenjen Romom.

$\mathrm{V}$ predlogu nove ReNPIO za obdobje 2012-2020 (2013) je med drugim zapisano, da je eden od dolgoročnih ciljev programa »opolnomočiti ljudi za delovanje, za refleksijo in za ustrezno odzivanje na socialne, politične, ekonomske, kulturne in tehnološke izzive ter za graditev skupnosti . Namera programa je tudi »uravnoteženo izobraževanje za razvoj človeškega (trg dela), socialnega (družbena povezanost, aktivno državljanstvo, medkulturni dialog) in kulturnega (osebnostni razvoj, razvoj vrednot) kapitala«. V kakšni meri se bodo cilji o uravnoteženosti razvoja vseh treh vrst kapitala dejansko uresničevali in koliko sredstev bo namenjenih izobraževanju za aktivno državljanstvo, bo odvisno od vsakokratne vladajoče koalicije in njenih prioritet. Politika izobraževanja odraslih se namreč ne oblikuje in uveljavlja izključno na podlagi strokovnih analiz in argumentov, ampak v velikem delu temelji na političnih interesih »od zgoraj navzdol «.

\section{UČENIE AKTIVNEGA DRŽAVLJANSTVA IN SODOBNA DRUŽBENA GIBANJA}

Številni strokovnjaki se strinjajo, da se izobraževanje za aktivno državljanstvo začne v dru- žini in šoli, nadaljuje pa se skozi vse življenje v različnih socialnih kontekstih. Razmeroma majhno število odraslih se udeležuje organiziranih izobraževalnih programov za aktivno državljanstvo, saj je ponudba tega izobraževanja nestabilna in niha iz leta $\mathrm{v}$ leto. Politike izobraževanja odraslih na nacionalni in nadnacionalni ravni namreč deklarativno podpirajo izobraževanje za aktivno državljanstvo, toda razhajanje med retoriko in realnostjo je pogosto veliko.

Odrasli se aktivnega državljanstva najpogosteje učijo priložnostno, v pogovoru, iz medijev in na spletnih straneh, kjer se lahko poučijo o ključnih konceptih, kot so: politična kultura, kultura dialoga, socialna in pravna država, predstavniška in neposredna demokracija itd. Pri tem ima pomembno vlogo medijska pismenost, tj. kritično razumevanje sporočil. Odrasli se aktivnega državljanstva učijo tudi skozi delovanje v civilni družbi in naprednih družbenih gibanjih. Različni avtorji (Holst, 2002; Crowther in Show, 1997; Dykstra in Law, 1994) so v družbenih gibanjih identificirali dve glavni obliki izobraževanja. Prva oblika izobraževanja je usmerjena navzven, in sicer v primerih, ko družbena gibanja s pomočjo različnih oblik javnega protesta poskušajo izobraževati in prepričati širšo javnost in politike. Druga oblika je interno izobraževanje, ki poteka znotraj družbenega gibanja. Lahko je neformalno in priložnostno, ko se s pomočjo mentorstva in izkustvenega učenja prenašajo organizacijske veščine, ideologija in alternativni življenjski slogi, ali bolj formalno, torej v okviru delavnic, predavanj, seminarjev itd. Poleg tega, da se ljudje skozi delovanje v družbenem gibanju učijo, je še pomembneje to, da se v okviru družbenih gibanj ustvarjajo in razširjajo nova znanja in razumevanja.

Državljani se vse bolj zavedajo pogubnih posledic neoliberalnih evropskih politik, ki temeljijo na globalni konkurenčnosti, 
svobodnem trgu, fleksibilizaciji delovne sile, privatizaciji javnih ustanov in družbene infrastrukture. Posledice teh politik se kažejo v odpravljanju socialne države, širjenju siromaštva, stopnjevanju intenzivnosti izkoriščanja in pojavu njegovih novih oblik ter v uničevanju naravnega okolja. Zaradi tega se v Sloveniji (in v drugih, zlasti perifernih članicah EU) aktivni državljani povezujejo v številnih omrežjih in družbenih gibanjih, ki so vzniknila med zadnjimi vstajniškimi demonstracijami. Ta gibanja imajo vse značilnosti sodobnih družbenih gibanj, ki rešitve ne vidijo $\mathrm{v}$ revolucijah in prevzemu oblasti, temveč v odpiranju političnega in družbenega prostora neposredni demokraciji. Poleg tega izstopa njihova sposobnost usklajevanja zelo različnih ekonomskih, političnih in socialnih zahtev v horizontalnih mrežah. Opaziti je, da kljub raznolikosti delujejo na podlagi vzajemnega spoštovanja medsebojnih razlik, solidarnosti in razumevanja. So tudi izrazito pluralistična, ideološko heterogena, imajo različne strategije. Sodobna družbena gibanja s pomočjo novih komunikacijskih tehnologij prenašajo svoje izkušnje in prakse delovanja na lokalni, nacionalni in mednarodni ravni. V globalni mreži gibanj je veliko vzajemnega učenja, ki temelji na izkušnjah delovanja

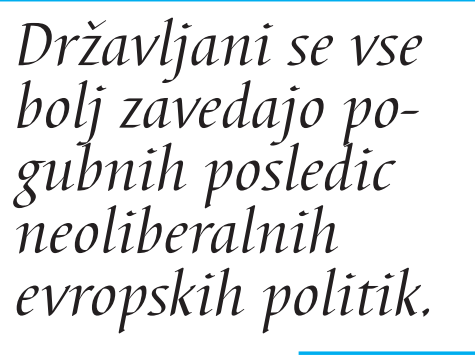

v različnih delih sveta. Gibanja s pomočjo svetovnega spleta vzpostavljajo povezave in krepijo medsebojno razumevanje, $s$ tem pa se večajo možnosti nenasilnega družbenega upora in graditve alternativnega sveta ter ustvarjanja alternativne družbenosti. Ker so sodobna politična gibanja del globalne mreže odpora, se širi zavest o planetarni povezanosti, s tem pa veliko prispevajo $\mathrm{k}$ mednarodnemu obveščanju in ozaveščanju širokega kroga ljudi.
Skupine in gibanja se učijo drug od drugega, izmenjujejo izkušnje delovanja. Zaradi narave najnovejših družbenih gibanj izobraževanje poteka nehierarhično, horizontalno, kolektivno, prevladuje vzajemno in sodelovalno učenje, ki spodbuja enakost, pravičnost, solidarnost, globalno spoštovanje ter zaščito ljudi in okolja. V izobraževalnih praksah sodobnih družbenih gibanj ni avantgardizma in paternalizma (ki sta bila značilna za stara družbena gibanja), vsi v izobraževanju imajo enak položaj in njihove ideje svobodno krožijo skozi socialne mreže. Velik del razprave, izmenjave izkušenj, novih oblik izobraževanja in učenja se dogaja prek svetovnega spleta.

V sodobnih družbenih gibanjih se izmenjujejo in združujejo znanja in izkušnje udeležencev raznolikih skupin, skozi procese vzajemnega učenja se vzpostavljajo zavezništva (»enotnost v raznolikosti«) in krepijo sposobnosti za skupno delovanje (Hall, 2009). Takšno učenje vključuje vsebine, kot so poglobljeno seznanjanje s problemi neenakih razmerij moči v družbi, pridobivanje znanja o mobilizaciji in organizaciji, o demokratičnih načinih sodelovanja, razvoj sposobnosti za kritične analize, alternativne diskurze in vizije, razumevanje razlik, spoštovanje različnosti, učenje o tem, kako doseči soglasje in kako pritegniti širšo javnost ter kako vzdrževati in krepiti dolgoročne strategije delovanja. Pomembna razsežnost učenja je tudi kritična refleksija o strategijah delovanja.

\section{ZAKLJUČEK}

V sedanjih kriznih razmerah kritični andragogi poskušajo ponovno obuditi izobraževalne prakse emancipacijskega in angažiranega izobraževanja odraslih, vendar se ob tem sprašujejo, ali so učitelji na področju izobraževanja 
odraslih resnično izobraževalci odraslih ali pa so le usposobljeni tehniki, ki prenašajo nevtralna znanja in spretnosti (Fragoso in Guimarães, 2010; Barros, 2012). Zanima jih, koliko današnji izobraževalci odraslih poznajo bogato dediščino izobraževanja odraslih, kjer je šlo za prizadevanje za demokratizacijo družbe, za bolj solidarno in pravično družbo, in koliko so seznanjeni s Freirejevo teorijo izobraževanja, ki je izobraževanje povezal s problemi zatiranja, socialne pravičnosti in emancipacije. Freire je trdil, da izobraževanje, čeprav pogosto promovirano $\mathrm{v}$ imenu socialne pravičnosti, lahko postane sredstvo zatiranja, reprodukcije vladajočega razreda ter vzdrževanja socialne neenakosti (Freire, 1970). Skozi svoje delo je prišel do spoznanja, da je vsako izobraževanje $\mathrm{v}$ bistvu politično dejanje. Bil je prepričan, da poučevanje ne sme biti ločeno od kritične analize delovanja družbe. Zaradi tega morajo učitelji in učenci kritično razmišljati o družbenih, političnih in zgodovinskih realnostih, v katerih živijo. Odgovornost učiteljev je povezovati izobraževanje in učenje s socialno pravičnostjo. Po Freireju (1988) je cilj izobraževanja odraslih krepiti demokracijo, s tem da se povečujeta politična neodvisnost in samostojnost državljanov, kot tudi krepita kritičen odnos do političnih odločitev in interes za sodelovanje v delu državnih ustanov. To je danes, ko v politiki in praksi prevladuje neoliberalna ideologija, še toliko pomembneje. Vladajoče skupine izvajajo nadzor nad tem, »kaj« se poučuje in »kako« se poučuje; skratka, kot bi rekel Gramsci, vzdržujejo hegemonski nadzor nad izobraževanjem.

Ko obravnavamo izobraževanje za aktivno državljanstvo, je treba na novo razmisliti o pomenu in značilnostih radikalnega izobraževanja odraslih, ki nakazuje mnoštvo idej, participativne in neavtoritarne oblike vzajemnega izobraževanja in učenja. Takšno izo- braževanje je zasnovano na prepričanju, da lahko ljudje le skupaj spremenijo obstoječe nepravične družbene odnose in da je drugačen svet možen. V takšnem izobraževanju je vsakdanja izkušnja pomemben vir učenja, toda treba jo je kritično preveriti in okrepiti v dialoških razpravah, študiju in kolektivnem delovanju. Radikalnost izobraževanja se kaže v prizadevanju, da ljudje spremenijo obstoječe pogoje življenja, ne pa, da se jim prilagajajo. Temelji na vrednotah enakosti in kolektivizma, razvija se iz pobud od spodaj. Motivirano je z željo, da se okrepi družbena zavest in moč skupin ter spodbuja progresivna družbena sprememba. Treba je poudariti, da pri radikalnih andragogih ne gre za romantično in utopično retoriko, saj v svojih razpravah ponujajo uporabne odgovore, ki izhajajo iz njihovega dejavnega angažmaja $\mathrm{v}$ različnih oblikah skupnostnega izobraževanja ter v mnogovrstnih družbenih in sindikalnih gibanjih.

V zaključku ugotavljamo, da potrebujemo izobraževanje odraslih, ki vključuje izobraževanje za aktivno državljanstvo, socialno vključenost in osebni razvoj, kjer ima svoje mesto tudi zaposljivost. Toda potrebujemo predvsem izobraževanje, ki odpira vprašanja o prihodnosti človeštva in našega planeta - in to je pomembnejše kot zaposljivost in pridobivanje dobička korporacij in različnih elit.

\section{LITERATURA IN VIRI}

Barros, R. (2012). »From lifelong education to lifelong learning: Discussion of some effects of today's neoliberal policies«. European Journal for Research on the Education and Learning of Adults, 2: 119-134.

Beltram, P., Drofenik, O., Možina, E. (2010). Analiza uresničevanja Resolucije o nacionalnem 
programu izobraževanja odraslih 20052008.

Ljubljana: Andragoški center Slovenije.

Borg, C., Mayo, P. (2006). Learning and Social Difference: Challenges for Public Educational and Critical Pedagogy. London: Paradigm Publishers.

Bourdieu, P. (1998). Acts of Resistance. Bristol: Polity Press.

Coffield, F. (2002). »Breaking the consensus«. V: Edwards, R., Miller, N., Small, N., Tatt, A. (ur.), Supporting Lifelong Learning. London.

Crowther, J. (2004). »'In and against' lifelong learning: flexibility and corrosion of character «. International Journal of Lifelong Education, 2: 125-136.

Crowther, J., Shaw, M. (1997). »Social movements and the education of desire «. Community Development Journal, 3: 266-279.

Davies, L. (1999). »Comparing definitions of democracy in education«. Compare: A Journal of Comparative and International Education, 2: 127-140.

Dykstra, C., Law, M. (1994). »Popular social movements as educative forces $«$. V: Hyams, M. (ur.), Proceedings of the $35^{\text {th }}$ Annual Adult Education Research Conference. Knoxville.

Europe for Citizens Programme (2013). Education, Audiovisual and Culture Executive Agency. Dostopno na: http://eacea.ec.europa.eu/citizenship/ index_en.php.

ET 2020 (2009). Education and Training 2020.

European Council. Dostopno na: http://ec.europa. eu/education/lifelong-learning-policy/policy-framework_en.htm.

European Commission (2000). A Memorandum on Lifelong Learning. Bruselj: SEC.

Evropska komisija - Slovenija (2013). Leto 2013 je evropsko leto državljanov. Dostopno na: http:// ec.europa.eu/slovenija/hp/2012-1128-evropsko-leto-državljanov_sl.htm.

Faure, E. (ur.) (1972). Learning to Be - The World of Education Today and Tomorrow. Pariz: UNESCO.

Fragoso, A., Guimarães, P. (2010). »Is there still a place for social emancipation in public policies?« European Journal for Research on the Education and Learning of Adults, 1-2: 17-31.
Freire, P. (1998). Pedagogy of freedom: ethics, democracy, and civic courage. Lanham: Rowman \& Littlefield Publishers.

Freire, P. (1970). Pedagogy of the oppressed. New York: Continuum.

Griffin, C. (1999). »Lifelong learning and welfare reform«. International Journal of Lifelong Education, 6: 431-452.

Hall, B. L. (2009). »A river of life: learning and environmental social movements «. Interface: a journal for and about social movements, 1: 46-78.

Holst, J. D. (2002). Social Movements, Civil Society and Radical Adult Education. Westport, Connecticut, London: Bergin \& Garvey.

Jarvis, P. (2007). Globalisation, lifelong learning, and the learning sociaty. New York: Routledge.

Martin, I. (2003). »Adult education, lifelong learning and citizenship: some ifs and buts...« International Journal of Lifelong Education, 6: 566-579.

Martin, I. (2006). »In whose interests? Interrogating the metamorphosis of adult education «. V: Antikainen, A., Harinen, P., Torres, C. A. (ur.), At the margins of adult education, work and civil society. Rotterdam.

Murphy, M. (2000). »Adult education, lifelong learning and the end of political economy«. Studies in the Education of Adults, 2: 166-180.

OECD (1989). Education and the economy in a changing society. Pariz: OECD.

Olssen, M. (2006). »Understanding the mechanisms of neoliberal control: lifelong learning, flexibility and knowledge capitalism«. International Journal of Lifelong Education, 3: 213-230.

Resolucija o nacionalnem programu izobraževanja odraslih za obdobje 2012-2020 (ReNPIO 2012-2020), januar 2013. Predlog programa je dostopen na državnem portalu: e-demokracija.si.

Rezultat razpisa (2011). Rezultat Javnega razpisa za programe neformalnega izobraževanja odraslih od 2012 do 2014. Ministrstvo za šolstvo in šport. Dostopno na: http://www.mizks.gov.si/si/okroznice_razpisi_in_javna_narocila/javni_razpisi/?tx_ t3javnirazpis_pi1\%5Bshow_single\%5D=1151. 
Rubenson, K. (2004). »Lifelong Learning: A Critical Assessment of the Political Project «. V: Alheit, P. (ur.), Shaping an Emerging Reality Researching Lifelong Learning. Roskilde.

Rubenson, K. (2009). »OECD educational policies and world hegemon«. V: R. Mahon, S. McBride (ur.). The OECD and transnational governance. Vancouver. 